\title{
PENGARUH EKSTRAK BERBAGAI BAGIAN TANAMAN MENGKUDU (MORINDA CITRIFOLIA) TERHADAP PERKEMBANGAN PENYAKIT ANTRAKNOSA PADA TANAMAN CABE (CAPSICUM ANNUUM L.)
}

\author{
Efrii $^{1}$
}

\begin{abstract}
Effect of extraction from some parts of Mengkudu (Morinda citrifolia) to suppress anthracnose disease on chili (Capsicum annuum $L$ ). The research was conducted to study the effect of extract from some parts of Mengkudu on the growth of anthracnose disease on chilli (Capsicum апnиит L). Some extraction of mengkudu parts such as from leaves, flowers and fruits and propineb fungicide were used in this research. Spore suspension of Colletotrichum capsici $\left(10^{8} \mathrm{spore} / \mathrm{ml}\right)$ used to inoculate chili plant one week before extraction of mengkudu (33 day after planting) was applicated. The result showed that application of leaf and flower extraction were effective to suppress disease incidence and severity, but fruit extraction was not effective. However, leaf and flower extraction did not significantly differ with propineb fungicide.
\end{abstract}

Key words : Mengkudu extraction (Morinda citrifolia), anthracnose diseases, chili (Capsicum annuиm L.)

\section{PENDAHULUAN}

Salah satu kendala utama dalam budidaya tanaman cabe adalah penyakit antraknosa. Penyakit yang disebabkan oleh jamur Colletotrichum capsici ini sering menimbulkan kerugian besar. Penyakit ini tidak hanya merugikan pada pertanaman di lapangan tetapi dapat juga menimbulkan kerugian pada saat pascapanen. Penyakit ini dapat menimbulkan kehilangan hasil mencapai 50\% (Pakdeevaraporn et al., 2005), bahkan di negara berkembang seperti di Thailand kehilangan hasil bisa mencapai 80\% (Than et al., 2008). Pada tahun 2002 di Provinsi Lampung khususnya di daerah Liwa sebagai sentra penanaman cabe kehilangan hasil akibat serangan patogen ini mencapai $70 \%$.

Colletotrichum capsici sebagai patogen penyakit antraknosa dapat menyerang setiap bagian tanaman. Serangan pada batang dan daun tidak menimbulkan masalah yang berarti bagi tanaman, tetapi dari bagian inilah penyakit dapat berkembang ke buah dan dapat menimbulkan masalah yang sangat serius. Collethotrichum sp. merupakan patogen yang perlu diperhatikan karena dapat menimbulkan infeksi laten (Jefries et al., 1990).
Buah yang terserang akan menimbulkan gejala bercak berwarna hitam dan dapat berkembang menjadi busuk lunak. Serangan yang berat dapat menyebabkan seluruh buah mengering, keriput dan buah menjadi rontok ke tanah. Patogen dapat juga menyerang pada buah yang sudah dipetik. Penyakit akan berkembang selama dalam pengangkutan dan dalam penyimpanan, sehingga panenan akan menjadi busuk dan menimbulkan kerugian yang lebih besar lagi.

Usaha pengendalian penyakit yang banyak dilakukan oleh para petani adalah penggunaan fungisida sintetis secara intensif. Pengendalian dengan fungisida sintetis dapat menimbulkan berbagai masalah (Than et al., 2008). Pengendalian seperti ini memerlukan biaya besar dan juga efek residunya dapat menimbulkan dampak negatif terhadap manusia dan lingkungan. Efek residu fungisida dapat mematikan jasad nirsasaran yang banyak bermanfaat bagi kelangsungan ekosistem di alam. Manusia sebagai konsumen tidak lepas dari pengaruh negatif residu fungisida yang terdapat pada buah cabe. Banyak bahan aktif pestisida dapat mengganggu kesehatan manusia, misalnya dapat merangsang pertumbuhan sel-sel kanker. Oleh karena

\footnotetext{
${ }^{1}$ Jurusan Proteksi Tanaman, Fakultas Pertanian, Universitas Lampung,

J1. Prof. Sumantri Brodjonegoro No. 1 Bandar Lampung 35145. E-mail: efri@ unila.ac.id
} 
itu penggunaan pestisida sebagai pengendali penyakit tanaman harus ditekan sekecil mungkin dan sebagai penggantinya harus dicari suatu bahan yang bersifat alami yang bertindak sebagai fungisida tetapi tidak berpengaruh negatif terhadap lingkungan maupun manusia. Beberapa ekstrak bagian tanaman yang mempunyai potensi sebagai biopestisida telah banyak diteliti, misalnya sweetflag (Acorus calamus L.), minyak palmorosa (Cymbopogon martini), ekstrak daun Ocimum sanctum dan neem (Azadirachita indica) dapat menekan perkembangan jamur penyebab penyakit antraknosa (Jeyalakshmi \& Seetharaman, 1998).

Tanaman mengkudu (Morinda citrifolia syn. M. lucida) atau pace pada saat ini menjadi sangat populer. Tanaman ini banyak terdapat di Indonesia sebagai tanaman liar atau tanaman pekarangan yang dimanfaatkan sebagai tanaman sayuran atau tanaman obat. Khasiatnya yang dapat menyembuhkan berbagai penyakit pada manusia mendorong banyak peneliti untuk melakukan penelitian tentang kandungan tanaman mengkudu. Kandungan senyawa kimia yang terdapat pada buah mengkudu diantaranya adalah saponin, tannins, anthraquinon dan senyawa alkaloid (Nwinji et al., 2008; Adejumobi et al., 2008). Ekstrak daun mengkudu pada konsentrasi $25 \mathrm{mg} \mathrm{ml}^{-1}$ mampu menghambat pertumbuhan Escherichia coli dengan zona penghambatan $5 \mathrm{~mm}$ (Ogundare \& Onifade, 2009) dan menghambat pertumbuhan jamur Penicillium, Fusarium, Rhizopus dan Mucor mendekati 50\% (Jayaraman et al., 2008). Hasil percobaan Efri (2004) menunjukkan bahwa ekstrak buah mengkudu dapat menekan pertumbuhan bakteri Ralstonia solanacearum, hanya saja penerapan pada tanaman masih perlu diteliti lebih lanjut. Berdasarkan ini diharapkan buah mengkudu juga dapat digunakan untuk menghambat pertumbuhan jamur $C$. capsici penyebab penyakit antraknosa pada tanaman cabe serta menekan perkembangan penyakit tersebut. Penelitian ini bertujuan untuk mempelajari pengaruh ekstrak mengkudu terhadap perkembangan penyakit antraknosa pada tanaman cabe.

\section{METODE PENELITIAN}

Percobaan ini dilaksanakan di Laboratorium Hama dan Penyakit Tumbuhan, Jurusan Proteksi Tanaman, Fakultas Pertanian, Universitas Lampung. Penelitian dimulai pada bulan September 2005 sampai dengan Februari 2006. Bahan yang diperlukan antara lain inokulum jamur Colletotrichum capsisi penyebab penyakit antraknosa pada cabe, bibit cabe varietas lado, media potato dextrosa agar (PDA) untuk membiakan jamur Colletotrichum. Ekstrak daun, bunga dan buah mengkudu diperoleh dengan menggunakan blender. Percobaan disusun dalam rancangan acak kelompok (RAK) dengan 3 ulangan. Masing-masing perlakuan pada setiap ulangan terdiri dari 3 tanaman. Perlakuan terdiri dari ekstrak daun mengkudu (P1), ekstrak bunga mengkudu (P2), ekstrak buah mengkudu (P3), fungisida propineb (P4) dan air steril sebagai kontrol (P5). Data yang diperoleh diolah dengan sidik ragam dan perbandingan nilai tengah antar perlakuan diuji dengan uji beda nyata terkecil (BNT) pada taraf nyata $5 \%$.

Penyiapan Tanaman Uji. Bibit cabe yang sebelumnya telah disemai di nampan dengan media semai campuran tanah dan pupuk kandang dengan perbandingan 1:2 ditanam di dalam polibag berukuran $5 \mathrm{~kg}$ yang telah berisi campuran tanah dan pupuk kandang dengan perbandingan 2:1 dan disusun berdasarkan masingmasing perlakuan. Lahan yang digunakan untuk menempatkan polibag sebelumnya dibersihkan dari gulma dan sisa-sisa akar tanaman dengan menggunakan sabit dan cangkul.

Penyiapan Isolat Colletotrichum capsici. Isolat C. capsici yang digunakan adalah isolat yang didapat dari buah cabe yang telah terinfeksi. Buah cabe yang terinfeksi $C$. capsici dipotong kecil-kecil dibagian perbatasan antara yang sehat dan yang sakit. Kemudian potongan-potongan tersebut didesinfeksi dengan larutan kloroks $10 \%$ selama \pm 30 detik lalu dibilas dengan air steril, selanjutnya diletakkan di atas tisu steril sampai kering. Potongan tersebut ditumbuhkan pada media PDA, kemudian dimurnikan dan diperbanyak untuk keperluan pengujian ini.

Pemeliharaan Tanaman. Tanaman cabe merah berumur 30 hari setelah tanam (hst) dipupuk dengan TSP sebanyak $10 \mathrm{~g}$ per tanaman dan $\mathrm{KCl}$ sebanyak $7 \mathrm{~g}$ per tanaman. Pada umur 44 hst dipupuk dengan urea sebanyak $7 \mathrm{~g}$ per tanaman. Setelah berumur $56 \mathrm{hst}$ tanaman dipupuk kembali dengan campuran urea, TSP dan $\mathrm{KCl}$ sebanyak $8 \mathrm{~g}$ per tanaman.

Penyiraman tanaman dilakukan setiap hari. Pada umur 25 hst, tanaman cabe dipasang ajir agar dapat berdiri kokoh dan mampu menopang tajuknya yang merimbun. Pemasangan ajir dengan cara ditancapkan ke dalam tanah dengan jarak $\pm 5 \mathrm{~cm}$ dari tanaman. 
Untuk mencegah serangan hama dan serangga vektor, semaian disemprot dengan insektisida berbahan aktif deltametrin $25 \mathrm{~g} \mathrm{l}^{-1}$ pada 3 hari sebelum semaian dipindahkan ke polibag.

Inokulasi. Biakan C. capsici yang berumur 7 hari dikerok kemudian ditambah air steril sampai mencapai kerapatan konidia C. capsici $10^{8}$ konidia $\mathrm{ml}^{-1}$. Suspensi C. capsici tersebut disemprotkan ke tanaman dan tanah pada polibag satu minggu sebelum penyemprotan ekstrak mengkudu pertama kali.

\section{Pembuatan Ekstrak Mengkudu dan Aplikasi.} Daun, bunga dan buah mengkudu masing-masing ditimbang sebanyak $100 \mathrm{~g}$, lalu dicuci dengan air steril kemudian masing-masing diblender dengan ditambah air steril $100 \mathrm{ml}$ dan disaring dengan menggunakan 4 lapis kain kasa sehingga terbentuk ekstrak. Hasil ekstraksi disebut aliquot atau larutan induk. Ekstrak mengkudu sesuai perlakuan diaplikasikan dengan cara disemprotkan pada tanaman yang telah dipersiapkan di polibag pada saat tanaman mulai berbunga ( $33 \mathrm{hst}$ ) dan selanjutnya dilakukan setiap minggu sampai saatnya panen. Konsentrasi yang digunakan adalah 5\% (v/v) untuk masing-masing ekstrak sedangkan fungisida berbahan aktif propineb diaplikasikan sesuai dengan konsentrasi anjuran yaitu $2 \mathrm{~g} \mathrm{l}^{-1}$.

Pengamatan. Pengamatan dilakukan pada dua minggu setelah aplikasi ekstrak mengkudu (95 hst) karena pada saat itu gejala pertama kali muncul kemudian dilakukan seminggu sekali sampai panen pertama dilakukan. Intensitas penyakit adalah tingkat kerusakan tanaman karena adanya serangan patogen atau adanya penyakit. Intensitas penyakit terdiri dari keterjadian penyakit (disease incidence) dan keparahan penyakit (disease severity), sehingga peubah yang diamati yaitu :

1. Keterjadian penyakit antraknosa pada buah cabe. Untuk menghitung keterjadian penyakit digunakan rumus :

$$
\mathrm{TP}=\frac{\mathrm{n}}{\mathrm{N}} \times 100 \%
$$

\footnotetext{
Keterangan :

$\mathrm{TP}=$ Keterjadian Penyakit (\%)

$\mathrm{n}=$ Jumlah buah yang terinfeksi/bergejala

$\mathrm{N}=$ Jumlah total buah yang diamati
}

2. Keparahan penyakit antraknosa pada buah cabe Keparahan penyakit dihitung dengan rumus :

$$
\mathrm{KP}=\frac{\sum(\mathrm{n} \times \mathrm{v})}{\mathrm{N} \times \mathrm{V}} \times 100 \%
$$

$$
\begin{aligned}
& \text { Keterangan : } \\
& \mathrm{KP}=\text { keparahan serangan }(\%) \\
& \mathrm{n}=\text { banyaknya buah dalam setiap kategori serangan } \\
& \mathrm{N}=\text { jumlah buah yang diamati } \\
& \mathrm{V}=\text { nilai numerik untuk tiap kategori serangan } \\
& \mathrm{V}=\text { nilai skor tertinggi }
\end{aligned}
$$

Skor berdasarkan interval serangan penyakit antraknosa pada buah cabe adalah :

Skor $0=$ tanpa serangan

Skor $1=$ gejala terjadi pada lebih dari $0-20 \%$ buah

Skor $2=$ gejala terjadi pada lebih dari $20-40 \%$ buah

Skor 3 = gejala terjadi pada lebih dari $40-60 \%$ buah

Skor $4=$ gejala terjadi pada lebih dari $60-80 \%$ buah

Skor $5=$ gejala terjadi pada lebih dari $80-100 \%$ buah

\section{HASIL DAN PEMBAHASAN}

Gejala penyakit baru tampak pada saat tanaman berumur 95 hari setelah tanam (hst). Hasil sidik ragam menunjukkan bahwa ekstrak mengkudu memberi pengaruh yang nyata terhadap keterjadian dan keparahan penyakit antraknosa pada buah cabe. Ekstrak bunga dan daun mengkudu memiliki pengaruh yang sama dengan fungisida pembanding dalam menekan keterjadian dan keparahan penyakit antraknosa pada buah cabe. Hal ini berarti kemampuan ekstrak bunga mengkudu dan daun mengkudu untuk menekan penyakit antraknosa relatif sama dengan fungisida sintetik propineb yang biasa digunakan oleh para petani cabe (Tabel 1 dan Tabel 2).

Keterjadian Penyakit Antraknosa. Pada pengamatan 95 hst dan 102 hst persentase keterjadian penyakit antraknosa pada tanaman cabe yang diberi perlakuan ekstrak bunga mengkudu dan fungisida berbeda nyata dengan persentase keterjadian penyakit antraknosa yang diberi perlakuan air steril sedangkan persentase keterjadian penyakit pada perlakuan ekstrak daun dan buah mengkudu tidak berbeda nyata bila dibandingkan dengan air steril (Tabel 1). Hal ini menunjukkan bahwa kemampuan ekstrak bunga mengkudu sama dengan fungisida propineb. Pada bagian bunga mengkudu 
terdapat berbagai senyawa yang dapat berfungsi sebagai antimikrobial seperti 2 methy-4 hydroxy-5-7 dimethoxyanthraquinon, 4-O- $\beta$-D-glucopyranosyl, (1-4)$\alpha$-Rhamnopyranoside, 5,8-dimethyl-epigenin-4-O- $\beta$-Dgalactopyranoside, Aracetin-7-O- $\beta$-D-glucopyranoside (Chan-Blanco et al., 2006).

Pada pengamatan 109 hst, persentase keterjadian penyakit antraknosa pada perlakuan ekstrak daun, bunga dan fungisida berbeda nyata dengan air steril berarti ekstrak daun dan bunga mengkudu dapat menekan keterjadian penyakit antraknosa pada buah cabe. Pada daun mengkudu juga terdapat berbagai senyawa yang dapat berfungsi sebagai senyawa antimikrobial seperti arginine, aspartic acid, $\beta$-sitosterol, citrifolioside B, cysteine, cystine, glutamic acid, glycine, histidine, isolleucine, Kaempferol 3-O- $\alpha$-L rhamnopyranosyl -1$6)-\beta$-D- glucopyronosyide, Kaempferol 3-O- $\beta$-Dglucopyranosyl -1-6)- $\beta$-D- galactopyranoside, leucine, methionine, phenylalanine, proline, quercetin 3-O- $\beta$-Dglucopyranoside (Chan-Blanco et al., 2006). Sedangkan ekstrak buah mengkudu persentase keterjadian penyakit tidak berbeda nyata dengan kontrol berarti ekstrak buah mengkudu tidak dapat menekan keterjadian penyakit antraknosa. Ekstrak buah mengkudu juga mengandung berbagai senyawa kimia seperti dammacanthal, scopololetin, morindone, alizarin, aucubin, nordamanthal, rubiadin dan anthraquinon glycosides (Chan-Blanco et al., 2006). Tetapi karena kandungan air pada buah mencapai 90\% (Chan-Blanco et al., 2006) maka kosentrasi senyawa-senyawa yang kimia yang terkandung juga rendah. Oleh sebab itu ekstrak buah mengkudu tidak menunjukkan pengaruh yang nyata terhadap keterjadian penyakit antraknosa. Secara jelas perkembangan keterjadian penyakit antraknosa pada buah cabe terlihat pada Gambar 1.

Dari Tabel 1 dapat dilihat bahwa ekstrak bagian tanaman mengkudu yang berpengaruh menekan keterjadian penyakit antraknosa pada tanaman cabe adalah bagian bunga dan daun. Ekstrak bunga berpengaruh lebih awal dibandingkan dengan ekstrak daun, namun pengaruhnya semakin berkurang dengan bertambah keterjadian penyakit. Sebaliknya ekstrak daun mengkudu menunjukkan pengaruh yang semakin meningkat dengan bertambahnya keterjadian penyakit, bahkan dapat menekan penyakit pada tingkat yang terendah setelah fungisida propineb. Berdasarkan hal ini dapat dikatakan daun mengkudu mempunyai pengaruh yang lebih baik untuk menekan perkembangan penyakit antraknosa cabe dibandingkan dengan ekstrak bagian tanaman mengkudu yang lain. Sejalan dengan hasil penelitian Ogundare \& Onifade (2009) bahwa ekstrak daun mengkudu pada konsentrasi $25 \mathrm{mg} \mathrm{ml}^{-1}$ mampu menghambat pertumbuhan Escherichia coli dengan zona penghambatan $5 \mathrm{~mm}$ dan menghambat pertumbuhan jamur Penicillium, Fusarium, Rhizopus dan Mucor mendekati 50\%. Ekstrak daun mengkudu dalam minyak essensial pada konsentrasi 1000 ppm dapat menekan pertumbuhan Aspergillus flavus (Verma et al., 2008).

Keparahan Penyakit Antraknosa. Percobaan juga menunjukkan hasil yang sama terhadap parameter keparahan penyakit antraknosa pada tanaman cabe. Pada pengamatan 95 hst dan 102 hst, persentase keparahan penyakit antraknosa pada tanaman cabe yang diberi perlakuan ekstrak bunga mengkudu dan fungisida memberikan pengaruh yang sama dalam menekan keparahan penyakit antraknosa sedangkan ekstrak daun belum menunjukkan pengaruh yang nyata. Ekstrak bunga mengkudu dapat menekan keparahan penyakit antraknosa pada buah cabe (Tabel 2). Secara jelas perkembangan keparahan penyakit antraknosa pada buah cabe terlihat pada Gambar 2.

Pada pengamatan 109 hst, persentase keparahan penyakit antraknosa pada tanaman cabe yang diberi perlakuan ekstrak daun, bunga mengkudu dan fungisida berbeda nyata dengan yang terjadi pada tanaman yang diberi air steril. Ekstrak buah mengkudu tidak berbeda nyata dengan air steril. Hal ini berarti ekstrak bunga dan daun mengkudu mempunyai kemampuan yang sama dalam menekan keparahan penyakit antraknosa. Tetapi tetap ada kecenderungan pengaruh ekstrak bunga mengkudu semakin berkurang dengan bertambahnya umur tanaman dibandingkan dengan pengaruh ekstrak daun mengkudu. 
Tabel 1. Keterjadian penyakit antraknosa pada buah cabe yang diperlakukan dengan ekstrak berbagai bagian tanaman mengkudu pada beberapa periode pengamatan

\begin{tabular}{cccc}
\hline \multirow{2}{*}{ Perlakuan } & \multicolumn{3}{c}{ Keterjadian penyakit (\%) } \\
\cline { 2 - 4 } & $95 \mathrm{hst}$ & $102 \mathrm{hst}$ & $109 \mathrm{hst}$ \\
\hline Daun & $4,17 \mathrm{ab}$ & $7,87 \mathrm{~b}$ & $9,97 \mathrm{ab}$ \\
Bunga & $0,00 \mathrm{a}$ & $0,00 \mathrm{a}$ & $11,67 \mathrm{bc}$ \\
Buah & $15,33 \mathrm{c}$ & $16,44 \mathrm{~b}$ & $24,94 \mathrm{~cd}$ \\
Profineb & $0,00 \mathrm{a}$ & $0,00 \mathrm{a}$ & $0,00 \mathrm{a}$ \\
Air steril & $10,00 \mathrm{bc}$ & $16,67 \mathrm{~b}$ & $46,67 \mathrm{~d}$ \\
\hline
\end{tabular}

Keterangan : Data hasil ditransformasi dengan transformasi $\sqrt{X+1}$

Notasi yang berbeda menunjukkan perbedaan yang nyata pada uji BNT dengan taraf $5 \%$.

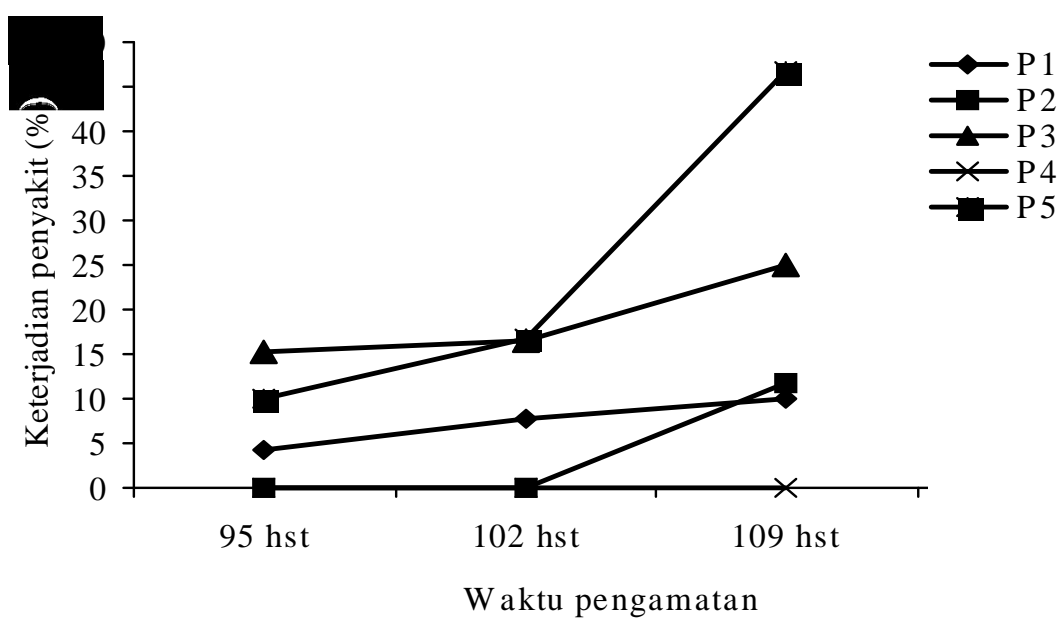

Gambar 1. Grafik keterjadian penyakit antraknosa pada buah cabe yang diberi perlakuan ekstrak berbagai bagian tanaman mengkudu (P1:daun; P2:bunga; P3:buah; P4:Propineb; P5:air steril) 
Tabel 2. Pengaruh ekstrak berbagai bagian tanaman mengkudu terhadap keparahan penyakit antraknosa pada tanaman cabe

\begin{tabular}{clcc}
\hline \multirow{2}{*}{ Perlakuan } & \multicolumn{3}{c}{ Keparahan penyakit (\%) } \\
\cline { 2 - 4 } & $95 \mathrm{hst}$ & $102 \mathrm{hst}$ & $109 \mathrm{hst}$ \\
\hline Daun & $0,83 \mathrm{ab}$ & $2,80 \mathrm{ab}$ & $4,40 \mathrm{ab}$ \\
Bunga & $0,00 \mathrm{a}$ & $0,00 \mathrm{a}$ & $4,10 \mathrm{ab}$ \\
Buah & $5,63 \mathrm{c}$ & $9,20 \mathrm{c}$ & $18,93 \mathrm{c}$ \\
Propineb & $0,00 \mathrm{a}$ & $0,00 \mathrm{a}$ & $0,00 \mathrm{a}$ \\
Air Steril & $4,67 \mathrm{bc}$ & $8,00 \mathrm{bc}$ & $23,67 \mathrm{c}$ \\
\hline
\end{tabular}

Keterangan : Angka yang tertera pada kolom merupakan rerata dari 3 ulangan

Data hasil ditransformasi dengan transformasi $\sqrt{X+1}$

Notasi yang berbeda menunjukkan perbedaan yang nyata pada uji BNT dengan taraf $5 \%$.

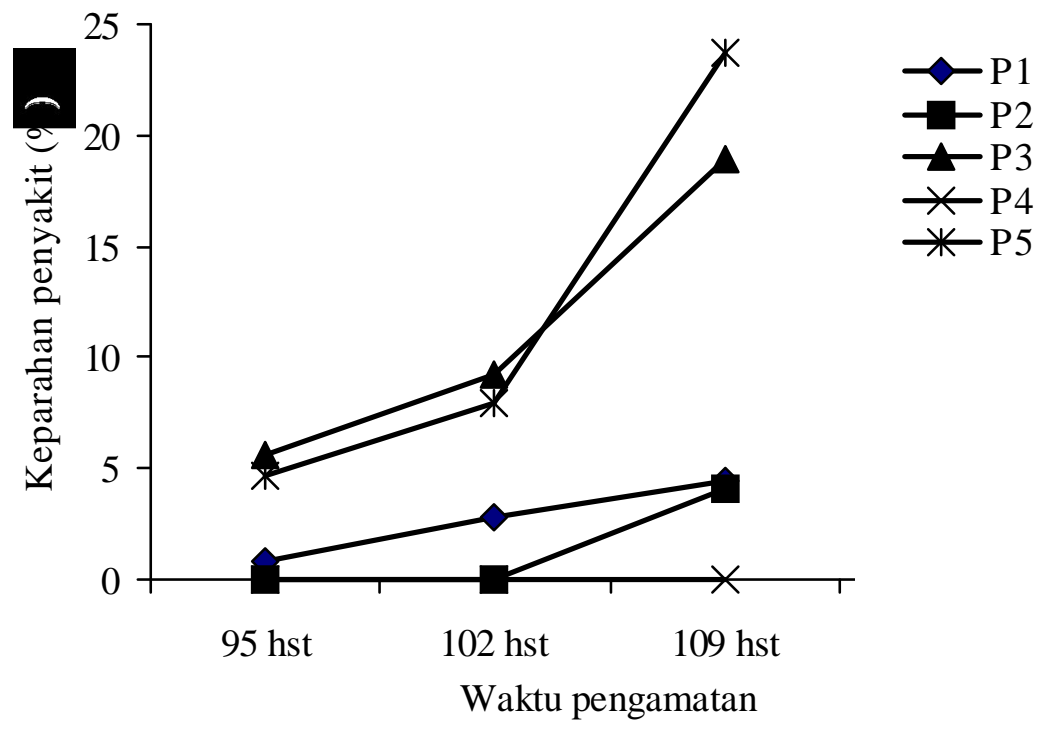

Gambar 2. Grafik perkembangan keparahan penyakit antraknosa pada buah cabe yang diberi beberapa jenis ekstrak bagian tanamam mengkudu (P1= daun; P2: bunga; P3:buah; P4: Propineb; P5: air steril) 


\section{SIMPULAN}

Dari hasil penelitian ini dapat disimpulkan bahwa:

1. Ekstrak daun mengkudu dan bunga mengkudu dapat menekan perkembangan ketejadian dan keparahan penyakti antraknosa tanaman cabe.

2. Pengaruh ekstrak daun mengkudu dan bunga mengkudu dalam menekan perkembangan penyakit antraknosa pada tanamam cabe tidak berbeda dengan fungisida sintetis berbahan aktif propineb.

3. Ekstrak buah mengkudu tidak mampu menekan perkembangan penyakit antraknosa pada tanaman cabe.

\section{DAFTAR PUSTAKA}

Adejumobi JA, Ogundiya MO, Kolapo AL \& Okunade MB. 2008. Phytochemical composition and in vitro antimicrobial activity of anogeisus lelocarpus o some common oral pathogen. J. Med. Plants Res. 2(8): 193-196.

Chan-Blanco Y, Vaillant F, Peres AM, Reynes M, Brillout JM \& Brat P. 2006. Critical Review: The noni fruit (Morinda citrifolia $\mathrm{L}$.): A review of agricultural research nutritional and therapeutic properties. Journal of Food Composition and Analysis 19: 645-654.

Efri. 2004. Efek Penghambatan Ekstrak Mengkudu terhadap Pertumbuhan Patogen dan Perkembangan Penyakit Bakteri Pada Tanaman Pisang. Jurnal Hama dan Penyakit Tumbuhan Tropika 4(1): 42-46.

Jeffries P, Dodd JC, Jegerand MJ \& Plumbley RA. 1990. The biology and control of Colletotrichum species on tropical fruit crops. Plant Pathology 39(3): 343-366.
Jayaraman SK, Manoharan MS \& Illanchezian S. 2008. Antibacterial, Antifungal and Tumor Cell Suppression Potensial of Morinda citrifolia fruit extracts. International Journal Of Integrative Biology (IJIB) 3(1): 44-49.

Jeyalakshmi C \& Seetharaman K. 1998. Biological control of fruit rot and die-back of chilli with plant products and antagonistic microorganisms. Plant Diseases Research 13: 46-48.

Pakdeevaraporn P, Wasee S, Taylor PWJ \& Mongkolporn O. 2005. Inheritance of resistance to anthracnose caused by Colletotrichum capsici in Capsicum. Plant Breeding 124(2): 206-208.

Nwinji OC, Chinedu NS \& Ajani OO. 2008. Evaluation of antibacterial activity of Pisidium guajava and Gongronema latifolium. J. Med. Plants. Res. 2(8): 189-192.

Ogundare AO \& Onifade AK. 2009. The Antimicrobial activity of Morinda lucida leaf exract on Escherichia coli. J. of Medicinal Plants Research 3(4): 319-323.

Than PP, Prihastuti H, Phoulivong S, Taylor PWJ \& Hyde KD. 2008. Chili anthracnose disease caused by Colletotrichum species. J. Zhejiang Univ. Sci. B. 9(10): 764-778.

Verma KR, Chaurasia L \& Katijar S. 2008. Potential antifungal plant for Controlling Building Fungi. Natural Product Radiance 7(4): 374-387. 